\title{
Problems and Prospects of the History of Mathematics Curriculum in China*
}

\author{
Lijuan Ren \\ Faculty of Education \\ Northwest Normal University \\ Lanzhou, China 730070 \\ Department of Education Science \\ Gansu Normal University for Nationalities \\ Hezuo, China 747000
}

\begin{abstract}
The study of the history of mathematics curriculum is an important part of constructing the mathematics curriculum system with Chinese characteristics. The study of mathematics curriculum history also helps to perfect and develop the mathematics curriculum theory, which is of great significance to the reform of mathematics curriculum in contemporary primary schools. As part of the study of the history of mathematics education in China, the study of mathematics curriculum in China has gradually attracted attention as a research field. At present, the research on the history of mathematics curriculum is still weak. The methodology of mathematics curriculum history research needs to be further improved and innovated. The research results of mathematics curriculum history are limited. The development of the history of mathematics curriculum should further create a multi-path of the study of the history of mathematics curriculum, expand the subject of curriculum history research and highlight the historical consciousness of curriculum history research.
\end{abstract}

Keywords-curriculum history study; mathematics curriculum; curriculum development

\section{INTRODUCTION}

The study of the history of mathematics curriculum is to excavate, organize and analyze the historical materials of mathematics curriculum, make a clear record, description and explanation of the "past" of the curriculum, and form some kind of explanatory structure on this basis, so as to provide reference and reflection on the current curriculum reform and practice. Since the 21st century, with the advancement and development of mathematics curriculum reform in China, more and more problems and difficulties have exposed in the curriculum reform process. In fact, many problems raised by the practice of mathematics curriculum reform have appeared in all the curriculum reforms. Due to the lack of in-depth analysis and summary of the curriculum reform process, it is impossible to provide historical experience and lessons for the current curriculum reform in the light of history and present. Therefore, it is necessary to

*Fund: Supported by 2017 The Ministry of Education of Humanities and Social Sciences Project (Grant No. 17XJC880007); Northwest Norma University 2017 Ph.D. Student Visit Program carry out more in-depth study of the history of mathematics curriculum, in the past curriculum reform to seek a warning meaning of curriculum wisdom.

\section{THE SIGNIFICANCE OF THE STUDY OF THE HISTORY OF MATHEMATICS CURRICULUMS}

\section{A. The Study of the History of Mathematics Curriculum Is an Important Part of Constructing the Mathematics Curriculum System with Chinese Characteristics}

Since the 21st century, the development of mathematics education in China has also made many important achievements. The Department for Education has invested 40 million pounds to support the promotion of the "Shanghai Master Teaching Model", including nearly half of all primary schools $(8,000)$ in England, using a full set of teaching materials and teaching aids for primary to sixth grades in Shanghai (36 in total). It is the responsibility of Chinese mathematics educators to comb and summarize the experience of Chinese mathematics curriculums and spread the experience of Chinese mathematics curriculums. The Chinese mathematics curriculum develops a complete system and it is the responsibility of the history of mathematics curriculum to organize and study the development system of Chinese mathematics curriculum. It is also an important perspective to construct the theory of Chinese mathematics curriculum to examine and study these problems from the historical point of view.

\section{B. Perfecting and Developing the Theory of Mathematics Curriculum}

First of all, the study of the history of mathematics curriculum is a strong support for the theoretical study of mathematics curriculum. And it is an important part of mathematics curriculum theory, but also an important part of mathematics education theory. Curriculum as an organism constantly changes and develops with the changes of the times. The development of mathematics curriculum in each stage is established and developed against the specific political, economic and cultural background. Through systematic combing and investigation through the historical 
context of mathematics curriculum, it is helpful to analyze the theoretical basis and social background on which mathematics curriculum depends. Secondly, theory and practice are closely linked; practice is the source of theory. The historical study of the development of mathematics curriculum, which is the study of the practice of mathematics curriculum at that time, through the examination of the practice of the curriculum, summarized and refined the law of the development of mathematics curriculum. For example, Taylor put forward the basic principles of curriculum development on the basis of the eight-year study experiment.

The curriculum practice is the suitable soil to nourish the curriculum research and provide rich resources for curriculum research, which provides rational guidance for curriculum reform and scientific basis for curriculum decision-making.

\section{It Is of Important Reference Significance to the Reform of Mathematics Curriculum in Contemporary Primary Schools}

"All educators, including curriculum experts, need a historical perspective that integrates the past and the present. Understanding history not only helps us not to repeat the mistakes of history in an abstract and realistic world, but also to prepare us better for the present." It is also necessary to know about how the reform of mathematics curriculum in history was carried out, how difficulties and problems were handled, and how to advance. Through the study of the development of mathematics curriculum in China, people will have a clearer understanding of the whole evolution of mathematics curriculum development, from which they can summarize some worthy of attention, with regular historical enlightenment. For example, how mathematics curriculum is not only oriented to the world, but also based on the country, that is, how to deal with the relationship between the theory introduced abroad and the reality of the country; how to combine the three elements of social development, students' psychological law and mathematics knowledge renewal in the preparation of mathematics curriculum, combined with historical experience, will provide a new perspective on how to effectively carry out the reform of mathematics curriculum in china in the course of mathematics curriculum reform.

\section{THE DEVELOPMENT OF THE HISTORY OF MATHEMATICS CURRICULUM IN CHINA}

Mathematics became a relatively independent field of study began with the west German scholar H. Bauersfeld (1976), who proposed three objects of mathematics education research at the Third International Conference on Mathematics Education in Germany in 1976: curriculum, teaching, and learning. Current study of the history of mathematics curriculum exists as part of the field of mathematics curriculum research.

Early research on the history of mathematics curriculum is more about curriculum research and the history of mathematics education, such as The Primary School Curriculum Evolution (Sheng Langxi, 1933) on the primary mathematics curriculum "arithmetic" related content. After the founding of New China, the study of the history of mathematics curriculum as part of the history of mathematics education, such as Yan Dunjie (1965) published A Brief History of Mathematics Education in China, introduced the early translation of relevant mathematics courses abroad. Wei Wei has introduced the content of mathematics curriculum in China since the late Qing Dynasty.

Wang Quan's History of Mathematics Teaching in Primary Schools in China (1996) combs and analyzes the teaching of mathematics in primary schools since ancient times. Since the end of the 20th century, with the rise of the study of the history of western curriculum and the beginning of a new round of curriculum reform in China, the study of the history of mathematics curriculum in China has also been carried out one after another. Zhang Yongchun's Mathematics Curriculum Theory (1996) discusses the curriculum evolution in the early days of the late Qing People's Republic. Lu Shihu's The History of Mathematics Curriculum in Chinese Middle School (2013) is the first book in China to systematically study the history of the development of Chinese middle school mathematics curriculum. From the perspective of the new curriculum reform, this question is "What kind of experience and enlightenment the history of mathematics curriculum development in Chinese middle school gives us", and from the perspective of the development of mathematics curriculum, that paper systematically discusses the history of mathematics curriculum in middle school in China from the perspective of the development of mathematics curriculum, and discusses the curriculum standards and related curriculums in various stages of China. On the basis of systematic combing and comprehensive analysis of historical materials such as teaching materials, history is taken as a guide and the enlightenment to the reform of mathematics curriculum today is given. Cao Chunyan's doctoral thesis, The Development of Middle School Mathematics Curriculum in the Republic of China (2016), Ye Beibei's doctoral thesis The Development of Mathematics Curriculum in New China Primary School (2014) respectively, carried out a systematic study of the history of middle school mathematics curriculum in the Republic of China and the history of mathematics curriculum in primary schools since the founding of New China. Wang Linquan's The Development of Mathematics Curriculum in Contemporary Primary and Secondary Schools (2006) is analyzed by combing and analyzing the development of ancient mathematics curriculum, modern mathematics curriculum development, modern mathematics curriculum development, and horizontal comparison. Liu Jicheng's 60 Years of Mathematics in Primary Schools (1949-2009) (2011) is dominated by the introduction of the main curriculum document and the background of curriculum standards. In the article A Review of the 70 Years of The Progress of the History of Mathematics Education in China, Daqin and others conducted research on the history of mathematics education in China in the early days, mainly from the mathematics education system and related teaching materials. The development of textbooks, as an important field of curriculum history research, has always been paid attention to. Chen Ting's doctoral thesis of Southwest University, The 
Evolution and Development of Chinese Junior Geometry Textbooks in the 20th Century (2008) for the first time systematically combed the historical changes of the preparation of Chinese junior high school geometry textbooks in the past hundred years. Zhang Wei's master's thesis China's Modern Mathematics Textbooks (2008), Wei Jia's doctoral thesis Reform and Development of The Content of Mathematics Textbooks in Primary Schools in China in the 20th Century (18) (2009) and Li Runquan's 50 Years of Mathematics Teaching Materials in Primary and Secondary Schools (1950-2000) (2008), the mathematics textbooks in China have been systematically combed since modern times.

The study of the history of mathematics curriculum in China has attracted more and more attention from experts and scholars from the early stage as a part of the study of the history of mathematics education to the research field of mathematics education.

\section{The CURRENT Problems IN THE StUdy OF THE HISTORY OF MATHEMATICS CURRICULUMS IN CHINA}

\section{A. Methodology of the Study of the Mathematics Curriculum History Needs to Be Further Improved and Innovated}

In the early stage, the history of mathematics curriculum in China was mostly more systematic analysis of curriculum documents, curriculum standards, textbooks, etc. Since the beginning of the 21 st century, the study of the history of mathematics curriculum in China has gradually established its own research framework, that is, the curriculum objectives, curriculum content, curriculum implementation and other aspects of the study of mathematics curriculum. With the curriculum history research gradually deepened and perfected, the study method of mathematics curriculum history also needs to be further improved and innovated by a new perspective. The new perspective analyzes and studies the history content of mathematics curriculum, and further promotes the study of the history of mathematics curriculums.

\section{B. The Study of Mathematics Curriculums History Is Limited}

As a historical study, the study of the history of mathematics curriculum needs to collect and occupy a large number of historical documents, but for various irresistible reasons, some historical data and documents have been lost or incomplete, so that the study is very difficult. On the other hand, the study of the history of mathematics curriculum needs researchers not only to have a deep grasp of curriculum history, curriculum theory, but also to have a deep understanding of mathematics curriculum. So the researchers are more demanding, and the study of curriculum history should also be subject to the overall social environment, mainstream ideology and value orientation and other factors. Therefore, the research results of curriculum history are limited in breadth, depth, value and marketability.

\section{THE Future Prospect OF THE StUdy OF THE HISTORY OF MATHEMATICS CURRICULUM IN CHINA}

\section{A. Creating a Multi-path for the Study of Mathematics Curriculum History}

At present, the study of the history of western curriculum has formed a variety of paths such as: to regard the history of curriculum as a cultural, social and educational history; to place the study of curriculum history in the field of social history or educational history research; to take curriculum history as a case study, mainly to explore the contribution of a character, school or curriculum experiment in history; to introduce the history of curriculum thought or practice, to regard curriculum history as one of the elements of an abstract curriculum textbook; to treat the curriculum history as a memorial and oral history; to regard the history of the curriculum as the editing of archives and documents, to cherish the collection and preservation of the curriculum materials; to regard the history of the curriculum as a biographical study; and the influence of postmodern thinking, the history of the curriculum as a voice of silence. (Chen Hua, 2012)

The study of the history of mathematics curriculum should draw lessons from the path of curriculum history research, and combine the characteristics of the history of mathematics curriculum, and create a multi-path of the study of the history of mathematics curriculum. The study of the history of mathematics curriculum shows new vitality.

\section{B. The Subject of Expanding the Study of the History of the Curriculum}

As mentioned earlier, most of the study of the history of Chinese curriculum focuses on curriculum standards, textbook sedation, in the early stage of curriculum history research has important value. But curriculum standards, textbooks are part of the curriculum history research, mathematics curriculum history research should be revitalized new activities and motivation. The subject of curriculum history research should be expanded, such as the study of major events in the history of mathematics curriculums: the history of mathematics curriculum summarizes the lessons of historical events which have a great influence on the curriculum history development, and provides historical experience and lessons for the current curriculum reform; the study of important figures in the course of the history of mathematics curriculums: from the perspective of curriculum history, the characters who have an important influence on curriculum development are studied; research on the history of curriculum reform: from the perspective of the history of curriculum reform, the development of curriculum history process can be seen.

\section{Highlighting the Historical Awareness of the Study of the History of the Curriculum}

The study of the history of mathematics curriculum should highlight its historical consciousness, draw lessons from the curriculum development, enrich and perfect the development of mathematics curriculum theory, and use the path of curriculum history research to revitalize the vitality 
of curriculum theory. Theory comes from practice, from the summary, combing and deepening of experience. And the study of the history of mathematics curriculum is the experience summary and systematicization of the history of the development of mathematics curriculum practice. The historical consciousness of the history study of mathematics curriculum is also reflected in the historical concern of the history of mathematics curriculum research, and the attention of the people in the course of mathematics curriculum development.

\section{CONCLUSION}

At the beginning of the 21 st century, the research of the history of mathematics curriculum in China has gradually attracted attention. From the beginning, the research of the history of textbooks has gradually expanded to the study of mathematics curriculum history in various aspects, such as mathematics teaching, mathematics teaching thought and so on. In this process, a research team, mainly composed of Professor Lu Shihu of Northwest Normal University and Professor Dai Qin of Inner Mongolia Normal University, has been formed to the history of mathematics curriculum systematically. However, there are still some problems in the study of the history of mathematics curriculum in China, such as the perfection and innovation of methodology. In the future, the study of the history of mathematics curriculum in China should try to create a pluralistic path, expand the research theme and highlight the historical consciousness of the study of the history of mathematics curriculum.

\section{REFERENCES}

[1] Li Shangliang, Ning Lianhua, Song Xiaoping. Thirty Years of Research on Mathematics Curriculum in Chinese Middle Schools [M]. Beijing: Science Press, 2012.

[2] Cui Chongyuan. "The Chinese Experience, The World Shares" [N]. CPPCC News, 2017-01-26.

[3] Shi Liangfang. The Basic Principles of Curriculum and Teaching [M]. Beijing: People's Education Press, 1994.

[4] Alan C. Ornstein, Francis P. Hankins, translated by Cosson. Curriculum. Basics, Principles, and Questions [M]. Nanjing: Jiangsu Education Press, 2002.

[5] Sheng Langxi. The Evolution of the Primary School Curriculum [M]. Shanghai: China Book Bureau, 1933.

[6] Yan Dunjie. A Brief History of Mathematics Education in China [J]. Chinese Mathematics Bulletin, 1965 (8)

[7] Wei Genren. History of Mathematics Education in Chinese Middle School [M]. Beijing: People's Education Press, 1987.

[8] Wang Quan. History ofMathematics Teaching in Primary Schools in China [M]. Jinan: Shandong Education Press, 1996.

[9] Zhang Yongchun. Mathematics Curriculum [M]. Guilin: Guangxi Education Press, 1996

[10] Lu Shihu. The History of Mathematics Curriculum in Chinese Middle School [M]. Beijing: People's Education Press, 2013.

[11] Cao Chunyan. The Development of Middle School Mathematics Curriculum in the Republic of China [D]. Lanzhou: Northwest Normal University, 2016.

[12] Ye Beibei. The Evolution and Enlightenment of Mathematics Curriculum in New China Primary School [D]. Lanzhou: Northwest Normal University, 2014.
[13] Wang Linquan. The Development of Mathematics Curriculum in Contemporary Primary and Secondary Schools [M]. Guangzhou: Guangdong Education Press, 2006.

[14] Liu Jiucheng. 60 Years of Primary Mathematics Curriculum [M] Zhenjiang: Jiangsu University Press, 2011.

[15] Da Qin, Li Chunlan. A Review of the 70 Years of Progress in the Study of the History of Mathematics Education in China [J]. Journal of Mathematics Education, 2007 (8). (In Chinese)

[16] Chen Ting. The Evolution and Development of Junior High School Geometry Textbooks in China in the 20th Century [D]. Chongqing: Southwest University, 2008.

[17] Wei Jia. Research on the Reform and Development of Mathematics Textbook Content in Primary Schools in China in the 20th Century [D]. Chongqing: Southwest University, 2009.

[18] Li Runquan, Chen Hongbo, Cai Shanghe, Fang Mingyi, Rao Hanchang. Fifty Years of Math Theaching Materials in Primary and Secondary Schools [M]. Beijing: People's Education Press, 2008.

[19] Chen Hua. The Research Path and Connotation of the History of Western Curriculum [J]. Global Education, 2012 (4). (In Chinese)

[20] Liu Zhijun, Wang Hongxi. Study on the History of The Curriculum: Issues and Prospects [J]. Educational Research, 2014 (8). (In Chinese) 